\title{
Taoist Philosophy in Chinese Science Fiction: A Comparison between Zhuangzi and Broken Stars
}

\author{
Aiqing Wang \\ University of Liverpool \\ Liverpool, United Kingdom \\ aiqing.wang@liverpool.ac.uk \\ Article History: Submitted on $18^{\text {th }}$ August 2021; Accepted on $15^{\text {th }}$ December 2021; \\ Published on $30^{\text {th }}$ December 2021
}

\begin{abstract}
Chinese science fiction has been attaining global visibility since Liu Cixin's trilogy entitled Remembrance of Earth's Past. The trilogy's English translator Liu Yukun has edited and rendered a science-fiction anthology entitled Broken Stars, which comprises sixteen novellas composed by fourteen Chinese novelists. Apart from a fecundity of imagination and richness of imageryevoking depictions, narratives compiled in the anthology also epitomise Taoist philosophy conveyed in Zhuangæi (aka Chuang Tæu), a Warring States (475-221 BC) treatise ascribed to an illustrious philosopher Zhuangzi. In this article, I hermeneutically scrutinise narratives in Broken Stars and compare and contrast them with Zhuangri, so as to illustrate the interconnection between science fiction and philosophy. I propound that philosophical constructs in the anthology can be exemplified by quintessential construals such as 'nonaction', 'resting in destiny' and 'self-so', as well as mindset appertaining to temporal and aesthetic issues in Zhuangzi.
\end{abstract}

Keywords: Ken Liu, speculative fiction, time travel, non-action

\section{INTRODUCTION}

China's science fiction is attaining international visibility. In 2015, a Hugo Award, the most prestigious international science-fiction prize, was bestowed upon an illustrious Chinese novelist 刘慈欣 Liu Cixin (1963- ) during the $73^{\text {rd }}$ World Science Fiction Convention, rendering him the first Asian Hugo Award laureate (Global Times, 2015; China Daily, 2019). Liu Cixin's chef-d'oeuvre is an award-winning science-fiction trilogy entitled 地 球往事 Diqiu Wangshi ‘Remembrance of Earth's Past', which is comprised of 三体 Santi 'The Three-Body Problem' (2006), 黑暗森林 Heian Senlin 'The Dark Forest' (2008) and 死神永生 Sishen Yongsheng 'Death's End' (2010) (China Writer, 2015; Li, 2015; Fan, 2019). The first and third volumes of the 
series have been rendered into English by a Chinese-born American lawyer and writer 刘宇昆 Liu Yukun (aka Ken Liu), who has translated a list of science-fiction works, such as 北京折叠 Beijing Zhedie 'Folding Beijing' by 郝 景芳 Hao Jingfang, 三体 X: 观想之宙 Santi X: Guanxiang Zhiøhou 'The Redemption of Time' by 宝树 Baoshu and 荒潮 Huangchao 'Waste Tide' by 陈楸帆 Chen Qiufan (Alter, 2019; Liu, 2019, p.1). In addition to translation, Ken Liu embarked upon his science-fiction creation on the threshold of the $21^{\text {st }}$ century: his novellas 手中纸, 心中爱 Shouzhongzhi Xinzhongai 'The Paper Menagerie' and 物哀 Wuai 'Mono no Aware' won the Hugo Award in 2012 and 2013 consecutively (Zhao, 2012; Zhang, 2016); the former novella was also the fiction work winning all three influential science-fiction awards, viz. Hugo, Nebula and World Fantasy Awards (Bai, 2016).

As Liu Yukun states in the introduction of a science-fiction anthology 'Invisible Planets' (看不见的星球 Kanbujiande Xingqiu) he has edited and translated, 'China has a vibrant, diverse science fiction culture' (Liu, 2016). In 2019, he edited and translated another science-fiction anthology entitled Broken Stars (碎星星 Sui Xingxing), which is constituted of sixteen novellas composed by fourteen Chinese novelists as well as three essays on sciencefiction literature (Henriksen, 2019; Zhao, 2019).

\section{METHOD}

Science fiction and philosophy are inextricably intertwined (Schneider, 2016), and science fiction used to be dubbed as 'the philosophic literature' (Myers, 1983, p.ix). In this research, I hermeneutically scrutinise Broken Stars (henceforward Stars) and Taoism (aka Daoism) by means of textual analysis and close reading, focusing in particular on philosophical constructs derived from a Taoist treatise 庄子 Zhuangzi (aka Chuang T₹u).

Zhuangzi is an anthology compiling the writing of an illustrious philosopher 庄子 Zhuangzi (aka Chuang-tzu or 'Master Zhuang', late $4^{\text {th }} \mathrm{c} \mathrm{BC}$ ) during the Warring States (475-221 BC) period (Hansen, 2014; Coutinho, 2016). Zhuangzi's exemplary construals are established on the teachings of 老子 Laozi (aka Lao-Tze, circa $6^{\text {th }} \mathrm{c}$ BC), a legendary thinker, the founder of a distinct Laoist school and the supreme deity of religious Taoism, whose chef-d'oeuvre is the canonical classic 道德经 Dao De Jing 'Tao Te Ching; Book of the Way and Virtue' illuminating Taoist thought and practice (Chan, 2000, 2018; Kirkland, 2004, p.42; Waley, 2005, p.20-21; Nadeau, 2014, p.65). Constituted of thirty-three chapters of the extant recension, Zhuangzi serves as a commentary on the Dao De Jing and plays a preponderant role in later literature, by virtue of its unparalleled fecundity of imagination illustrated via metaphors, allegories, parables and fables in an integrated form of prose and poetry (Mair, 2000). Moreover, Zhuangæi encompasses pivotal philosophical strands and conceptions exemplified by 道 Dao, 无为 wuwei 'non-action', 逍 
遥 xiaoyao 'free and easy wandering' and 自然 ziran 'naturalness' (Liu, 2015a, 2015b), as well as practices such as 坐忘 quowang 'sitting in oblivion' (Chan, 2000), which encapsulate 'humanism, naturalism, mysticism, and even aspects that foreshadow postmodernism' (Liu, 2015c, p.129). Its '[p]hilosophical positions and arguments can be discerned on a variety of issues concerning knowledge, language, meaning, imagination, ethical evaluation, emotions, social involvement, social exclusion, human behavior, skillful practice, and life and death' (Coutinho, 2016, p.159).

\section{FINDINGS AND DISCUSSION}

In Stars, Liu Yukun compiles a novella 大时代 Dashidai 'What Has Passed Shall in Kinder Light Appear' composed by a prolific writer 李俊 Li Jun, who is more renowned by his pseudonym 宝树 Baoshu (Gu, 2020). The narrative can be regarded as a speculative fiction work or Alternate History, featuring a man's entire life, during which real historical events and personages are represented in a reverse order; the narrative deploys philosophy as a premise and entails fundamental philosophical questions (Watson, 2015; Liu, 2019, p.145). Example (1) alludes to philosophers JeanPaul Sartre and Zhuangzi as well as an anecdote concerning monkeys, which draws on a parable in Chapter 齐物论 Qimu Lun 'Discussion on Making All Things Equal; On the Equality of Things' extracted from Zhuanga?'s fascicle 内篇 Nei Pian 'Inner Chapters'.

(1) “我听说, 庄子写过这样一个故事: 如果你早上给猴子三枚果子, 晚 上给猴子四枚果子, 猴子就会很不高兴, 但是如果你早上给它四枚, 晚 上给它三枚, 它就会很高兴。你看, 这只猴子是不是很愚蚌呢?” “㕪... 是啊, 这是朝三暮四的故事。”我说。萨特有些嘲讽地笑了笑: “您看 出问题所在么? 我们人类和猴子又有何不同? 难道我们追求的只是一 个“正确的’历史顺序吗? 就好像将幸福和不幸顺序颠倒一下, 一切就正 常了一样! 如果历史中的恶存在, 那么无论顺序如何改变, 它难道会因 此消失么?”

'I know that the Chinese once had a philosopher named Zhuangzi. He told this story: If you give a monkey three nuts in the morning and four nuts in the evening, the monkey will be unhappy. But if you give the monkey four nuts in the morning and only three in the evening, the monkey will be ecstatic. In your view, is the monkey foolish?' 'Uh ... yes. Zhuangzi's monkey is a byword for foolishness among the Chinese.' A mocking glint came into Sartre's eyes. 'But how are we different from the monkey in that story? Are we in pursuit of some "correct" order of history? If you switch happiness and misfortune around in time, will everything appear "normal" to you? If evil 
exists in history, does it disappear merely by switching the order of events around?'

(What Has Passed Shall in Kinder Light Appear. Chapter 14. Trans. Liu, 2019, p.205-206)

I propound that the novella What Has Passed Shall in Kinder Light Appear bears similitude to Zhuangzi's philosophical construct, as indicated in Example (2). Examples (1-2) illustrate that humans' perception of truth might be reduced to pure surmise (Kupperman, 1989; Peerenboom, 1993, p.209; Radice, 2001), in that judgements and the laws of nature are induced by emotional reaction to life events and inductive reasoning respectively (Kohn, 2014, p.38-39, 223-224). Knowledge is attributed to subjective power of intellectually processing reality and attaining understanding via recognition and representation (Zhang, 2002, p.423-424), but given the fact that knowledge entails 'second coding' (Moeller, 2003), it is prone to limitation and fault (Ivanhoe, 1993, 1996; Wong, 2005).

(2) 凡物无成与毁, 复通为一。唯达者知通为一, 为是不用而寓诸庸。 庸也者, 用也; 用也者, 通也; 通也者, 得也; 适得而几矣。因是已。已 而不知其然, 谓之道。劳神明为一, 而不知其同也, 谓之 “朝三”。何谓 “朝三”? 狙公赋芧, 曰: “朝三而暮四。”众狙皆怒。: “然则朝四而暮 三。”众狙皆悦。名实未元, 而喜怒为用, 亦因是也。是以圣人和之以 是非而休乎天钧, 是之谓两行。

Nothing is either complete or impaired, but all are made into one again. Only the man of far-reaching vision knows how to make them into one. He has no use for categories, but relegates all to the constant. He relies upon this alone, relies upon it and does not know he is doing so. This is called the Way. But to wear out your brain trying to make things into one without realizing that they are all the same-this is called 'three in the morning'. What do I mean by 'three in the morning'? When the monkey trainer was handing out acorns, he said, 'You get three in the morning and four at night.' This made all the monkeys furious. 'Well, then,' he said, 'you get four in the morning and three at night.' The monkeys were all delighted. There was no change in the reality behind the words, and yet the monkeys responded with joy and anger. Let them, if they want to. So the sage harmonizes with both right and wrong and rests in Heaven the Equalizer. This is called walking two roads.

(Chuang Tru. Discussion on Making All Things Equal. Trans. Watson, 1968, p.41)

Another novella in the anthology also concerns mindset towards history. 晋阳三尺雪 Jinyang Sanchi Xue 'The Snow of Jinyang' composed by 张申 Zhang Ran falls into the genre of 穿越 chuanyue 'time travel' and bears similitude to Mark Twain's A Connecticut Yankee in King Artbur's Court, according to the translator, the text abounds in 'playful references to popular 
tropes in chuanyue fiction, actual history, and contemporary life' (Liu, 2019, p.265-266). In the narrative, the time traveller's endeavours to alter history via advanced modern technology turns out to be in vain. Analogously, Zhuangzi can be interpreted from nihilistic and evolutionist perspectives that humans are incapable of impinging upon the world or creating auspicious future (Wu, 1982, p.7; Kohn, 2014, p.180).

As stated in Zhuangri, the 'Great Dao' is deemed as the essential course of cosmic history linking past to future, with which all humans and objects comply (Hansen, 2014). The temperament or inherent characteristic tendencies of human beings, viz., their 'inner nature', are ascribed to vital energy (Shun, 1997), yet the destiny and personal trajectories of individuals are determined by heaven and the force of external circumstances (Ames, 2001). In other words, human life enriched by aspirations in societal and natural environment is impinged upon by an interwoven framework of perimeters and limitations (Kohn, 2014, p.101). Zhuangri illustrates the ineluctable life and decease with the passage of time (Graham, 1989, p.190; Raphals, 2003, p.544) that is construed as a predictable and perpetual sequence of extended phases of presence (Moeller, 2004, p.95-98; Poo, 2005, p.110). As a consequence, it is vain for the mortals to express lamentations or dolorousness, as indicated by Examples (3-4) (Kohn, 2014, p.106).

(3) 若死生为徒, 吾又何患!

Since life and death closely follow each other, why whine about either?

(Chuang Tzu. Knowledge Wandered North. Trans. Kohn, 2014, p.106)

(4) 达生之情者, 不务生之所无以为。

Connecting to the core of life, do not labor over what life cannot do.

(Chuang Tzu. Mastering Life. Trans. Kohn, 2014, p.106)

In Stars, 倒影 Daoying 'Reflection’ by 顾适 Gu Shi concerns omniscience and multiple personalities. The mindset conveyed in Example (5) is consistent with the doctrines of 无为 wuwei 'non-action' and equanimity towards life and decease advocated by Zhuangzi (Liu, 1994, p.xv-xvi).

(5) “预言是她的记忆? 这真是太神奇了!”我却感到十分沮丧, “可你难 道不明白吗? 如果她说的是真的, 那么未来就是不可改变的, 而我们现 在所做的一切都是徒劳。这样的世界太让人绝望了。”“那你会怎么 做?”他总是喜欢这样引导我。我说: “我会选择不去相信。”

'She predicts the future from her memories? Fascinating!' I didn't share his enthusiasm. 'Don't you understand? If what she told me is true, then the future is unchangeable. Everything we do is wasted effort. How can you not despair at such a world?' 'So what are you going to do?' That was always Mark's style: teaching by asking us to find the answers ourselves. 'I choose to not believe in such a world.'

(Reflection. Chapter 2. Trans. Yan \& Liu, 2019, p.378) 
In terms of the novella 月夜 Yueye 'Moonlight', it is not the most celebrated work of Liu Cixin, but the author exhibits his literary aptitude by means of 'presenting idea after idea in a dizzying fusillade' (Liu, 2019, p.52). Parallel to the standpoint expressed in Example (5), Example (6) recounts a quotidian human's recurrent, unsuccessful attempts to change the course of history and save the world, so in the end, the character decides to comply with the precept of 'non-action'. As stated in Chapter 人间世 Renjian Shi 'In the World of Men; The Human World' extracted from the fascicle 内篇 $\mathrm{Nei}$ Pian 'Inner Chapters', one's compliance with fate is commendable (Example (7)).

(6) 但他立刻想到更重要的事, 删除了两个来自未来的电子邮件和所 有的附件, 又想了想, 他决定把硬盘低级格式化。当低格的进度条走 到头时, 这个夜晚又变成了普通的一夜, 这个曾在这一夜三次改变人 类历史, 但最终什么都没改变的人, 在电脑前睡着了, 外面曙光初现, 世界又开始了普通的一天, 真的什么都没有发生过。

Then he remembered that he had more important tasks. He deleted the emails and all attachments. Then, after a moment, he began to reformat the disk and zero out the sectors with multiple passes. By the time the reformatting had completed, it was just another ordinary night. The man who had changed the course of human history three times in a single night but who in the end had changed nothing fell asleep in front of his computer. Dawn brightened the eastern sky. The world began another ordinary day. Nothing had happened, at all.

(Moonlight. Trans. Yan \& Liu, 2019, p.71)

(7) 自事其心者, 哀乐不易施乎前, 知其不可奈何而安之若命, 德之至 也。

And to serve your own mind so that sadness or joy do not sway or move it; to understand what you can do nothing about and to be content with it as with fate- this is the perfection of virtue.

(Chuang Tru. In the World of Men. Trans. Watson, 1968, p.60)

In Zhuangzi, destiny is formulated in the form of fatalism as a predetermined course dictated by impersonal, consistent power (Chen, 1997a, 1997b; Zhang, 2002, p.126; Raphals, 2005, p.72), and by heaven as 'a quasipersonified, impartial, natural force' (Schwartz, 1985, p.126; Nylan, 1993, p.35; Fraser, 2011, p.102), as indicated by Examples (8-9). Humans' impotence in the face of destiny is reflected in a wide range, such as appearance, health, family, obligation and social status (Fraser, 2011, p.99), so the ideation of 安命 anming 'resting in destiny' is advocated (Raphals, 2003, p.242; Lenehan, 2020), namely, embracing circumstantial trajectories as immanent, vibrant changes of with equanimity (Barnwell, 2013, p.37). 
(8) 性不可易, 命不可变, 时不可止, 道不可雍。

Inner nature cannot be changed, destiny cannot be altered, time cannot be stopped, and Dao cannot be obstructed.

(Chuang Tzu. The Turning of Heaven. Trans. Kohn, 2014, p.106)

In terms of 开光 Kaiguang 'Coming of the Light' composed by 陈楸 帆 Chen Qiufan, it concerns apprehension, dynamism and absurdity of life (Liu, 2019, p.397) and is acclaimed as a cyberpunk work with Chinese characteristics and realistic elements such as religious practices, entrepreneurial drives and marketing strategies (Chao, 2015). Chen Qiufan's writing is featured by integration of high technology and abstruse witchcraft as well as coexistence of science and the so-called 玄学 Xuanxue $\mathrm{Neo}$ Daoism; Dark Learning' that implies obscureness, insubstantiality and arcaneness (Chan, 2010; D'Ambrosio, 2016; Lynn, 2016). For instance, in his chef-d'oeuvre $W$ aste Tide, 'the pinnacle of near-future SF writing' (Liu, 2019, p.397), Chen Qiufan depicts superstitious rites in his hometown, China's Chaoshan region, in a cyberpunk manner, which illuminates the similitude between science fiction and mythology and enriches his writing with religious representation (Dong, 2020; Yu, 2021). His prowess of combining ancient and modern elements is also reflected by his science fiction written in Classical Chinese (Liu, 2016). The expression kaiguang in the title is a Buddhist terminology denoting rituals of Buddha image consecration (Buswell \& Lopez, 2013, p.150), so I posit that Coming to Light embodies the author's stance that science and Xuanxuan are fundamentally identical (Dong, 2020).

The illumination in the Inner Chapters indicates that human beings are naturally social animals and hence execute natural causal processes and leave marks in nature, all of which are physically accessible to predecessors as history and reminiscences (Hansen, 2014). The depiction extracted from Coming to Light (Example (9)), however, accords with the epistemological plausibility of human beings living in a computer stimulation (Bostrom, 2016) as well as Zhuangzi's construal that the nothingness serves as the universal utmost (Liu, 2015b).

(9) “是的, 我知道这很难接受, 可这是真的。某人, 或者某些人做了一 些事情, 可能会威胁到整个程序——我们所处在的这个宇宙的稳定性, 于是系统按照事前设定好的机制, 发动 NPC, 执行指令, 消除威胁, 保 证宇宙的自洽性。”“可我以为我所做的一切全是出于自由意志, 我只 想把活儿干好, 混口饭吃。我以为我是在帮他。” “所有的 NPC 都这 么想。”

'I know it's hard to accept, but it's the truth. Someone, or maybe some group, has done things that threaten the entire program-the stability of our universe. And so the system, following designated routines, has invoked the 
NPCs to carry out its order to eliminate the threat and maintain the consistency of the universe.' 'But I did everything on my own! I just wanted to do my job and earn a living. I thought I was helping him.' 'All NPCs think like that.'

(Coming to the Light. Chapter 2. Trans. Yan \& Liu, 2019, p.427)

Zhuangzi encapsulates 'an aesthetic sensitivity that celebrates rebelliousness, intuitive insight, mysticism, and irrationality' (Nadeau, 2014, p.65). In Stars, 未来病史 Weilai Bingshi 'A History of Future Illnesses' composed by Chen Qiufan pertains to the impingement of technology on humans' body, cognition and societal relations (Dong, 2020; Shen, 2020). Example (10) depicts an aberrant aesthetic trend prevailing in ancient China, which is rejuvenated in the contemporary era and facilitated by high technology. As suggested by the translator Liu Yukun, '[i]ts Hieronymus Bosch-like visions of the future are dominated not so much by an allpowerful, know-nothing brutish state, but an apathetic, amoral, ahistorical populace for whom the end of history is both a blessing and curse' (Liu, 2019, p.398). The satire on the aberrant aesthetic trend in Example (10) accords with Zhuangzi's aesthetic stance embodied in 知北游 Zbibei You'Knowledge Wandered North' from 外篇 Wai Pian 'Outer Chapters', as shown in Example (11).

(10) 伴随著审美意识形态的去男性中心化, 塑身美容技术在 21 世纪中 叶发展到巅峰, 身体表面的改造工艺已不能够满足日新月异的多元族 群需求, 一种新的, 或者说古老的美学潮流重新复苏, 蔚为奇观。该潮 流可追溯到中国魏晋时期...五石散所带来的副作用却成为士大夫阶 层所追求的时尚, 所谓燥热急痴, 一边轻装缓带, 一边神游天外, 长期 服用, 性情急躁, 精神恍惚, 一如嵇康拔剑逐蝇。服石之风流行了五六 百年至唐, 诗文间 “行散”二字成为高贵的身份标签, 仿佛垮掉一代的 大麻或 LSD ...现在, 高科技可以帮助你。韧带收缩剂可在有效时间内 减小关节活动的幅度, 配合微量河豚毒素的面部肌肉注射, 可塑造出 东洋古典主义的姿态及表情控制。

As changing beauty standards gradually decentered the straight male gaze, plastic surgery reached a peak of inventiveness in the mid-twenty-first century. But modification of the body's external characteristics was no longer sufficient to satisfy the shifting tastes of a diverse population. A new-or more accurately, ancient-aesthetic trend came back into fashion spectacularly. It was possible to trace this trend all the way back to the Three Kingdoms and Jin Dynasty period (220 to 420 CE)...Consuming Five Minerals Powder for its psychoactive properties became the fashion among scholar-officials. After ingesting the powder, the typical user became restless, anxious, flushed, and had to walk about in loose clothing to cool down as their mind wandered a different plane. Habitual use led to irritability, 
explosive temper, and a proclivity for trances-not unlike the man of legend who reacted to a nettlesome fly by chasing after the insect with an unsheathed sword. The fashion for taking Five Minerals Powder in China lasted for almost six centuries, until the Tang Dynasty. 'Rambling Powder' became a poetic marker for those of an elevated social class - a metonymic process similar to the social signals attached to marijuana or LSD use later... And now, technology could help. Ligament tightening agents temporarily reduced the joints' range of motion; combined with trace amounts of tetrodotoxin injected into facial muscles, the result was a simulation of the stiff poses and expressions associated with classical East Asian beauty standards.

(Coming to the Light. Chapter 2. Trans. Yan \& Liu, 2019, p.426-427)

(11) 天地有大美而不言, 四时有明法而不议, 万物有成理而不说。圣人 者, 原天地之美而达万物之理, 是故至人无为, 大圣不作, 观于天地之 谓也。

Heaven and earth have their great beauties but do not speak of them; the four seasons have their clear-marked regularity but do not discuss it; the ten thousand things have their principles of growth but do not expound them. The sage seeks out the beauties of Heaven and earth and masters the principles of the ten thousand things. Thus it is that the Perfect Man does not act, the Great Sage does not move - they have perceived [the Way of] Heaven and earth, we may say.

(Chuang T₹u. Knowledge W andered North. Trans. Watson, 1968, p.236)

Moreover，宇宙尽头的餐馆：腊八粥 Yu₹hou Jintoude Canguan: Labazhon 'The Restaurant at the End of the Universe: Laba Porridge' composed by 吴霜 Wu Shuang (aka Anna Wu) also captures the interaction and correlation between human beings and internal and external worlds. The narrative 'starts as a Douglas Adams riff, then spins in a sadder, more intimate direction' (Henriksen, 2019), and Example (12) pertains to one's mentality towards self and all objects and creatures. Zhuangzi exhibits the terminology 自然 ziran that means 'nature' in modern Chinese yet 'self-so' 'in a manner of self-becoming, self-generating, self-directing, self-evolving' in the classic (Nadeau, 2014, p.70). Ziran highlights the aspiration of becoming a perfected person via the conduct of complying with one's inner nature and purifying mind and organs of sentience (Mair, 2000), as in Example (13).

(12) 爱才是一切事物中最重要的。戊平静地说。用尽所有的写作技 巧和智慧, 你能看透这个世界, 解释它, 荗视它, 却依旧无法成为最优 秀的文学大师。你要做的, 是放下自我, 融入世界, 不对抗也不憎恨; 用爱与敬畏来观察所有生物以及人类自身——这才是文学的终极奥 义。 
'Love was the most important thing of them all,' E said tranquilly. 'Technique and intelligence will let you see through the world, explain it, look down upon it, but they'll never make you a true master of literature. You have to let go of yourself, join yourself to the world without resistance or hate; use love, admiration, and respect to observe all living things, including humanity. This is the true secret of literature.'

(The Restaurant at the End of the Universe: Laba Porridge. Trans. Yan \& Liu, 2019, p.348-349)

(13) 天下莫大于秋豪之末, 而大山为小; 莫寿乎歾子, 而彭祖为天。天 地与我并生, 而万物与我为一。既已为一矣, 且得有言乎? 既已谓之一 矣, 且得无言乎? 一与言为二, 二与一为三。自此以往, 巧历不能得, 而 况其凡乎! 故自无适有, 以至于三, 而况自有适有乎! 无适焉, 因是已。

There is nothing in the world bigger than the tip of an autumn hair, and Mount T'ai is tiny. No one has lived longer than a dead child, and P'engtsu died young. Heaven and earth were born at the same time I was, and the ten thousand things are one with me. We have already become one, so how can I say anything? But I have just said that we are one, so how can I not be saying something? The one and what I said about it make two, and two and the original one make three. If we go on this way, then even the cleverest mathematician can't tell where we'll end, much less an ordinary man. If by moving from nonbeing to being we get to three, how far will we get if we move from being to being? Better not to move, but to let things be!

(Chuang Tzu. Discussion on Making All Things Equal. Trans. Watson, 1968, p.43)

\section{CONCLUSION}

Narratives in the anthology Stars embody pivotal construals and teachings in Zhuangzi. Plots pertaining to history accord with Zhuangzi's parable concerning knowledge and perception, and unsuccessful endeavours through time travel is consistent with a fatalistic interpretation of Zhuangzi that humans are incapable of impinging upon the world or creating auspicious future. Therefore, Zhuangzi advocates the precepts of 'non-action' and 'resting in destiny', as reflected in novellas Reflection by Gu Shi and Moonlight by Liu Cixin, both of which convey humans' meritorious compliance with fate. As for Chen Qiufan's Coming of the Light, it integrates Xuanxue, religious representation and cyberpunk elements, and it captures the fundamental question of existence. Furthermore, novellas in Stars also accord with Zhuangzi's aesthetic stance and 'self-so' highlighting one's inner nature. Therefore, it can be concluded that science-fiction novellas in Stars and philosophy reflected in Zhuangzi are intertwined. 


\section{REFERENCES}

Alter, A. (2019). Why Is Chinese Sci-Fi Everywhere Now? Ken Liu Knows. New York Times. $06 \quad$ December 2019. https://cn.nytimes.com/culture/20191206/ken-liu-three-bodyproblem-chinese-science-fiction/dual/.

Ames, R. T. (2001). The Local and the Focal in Realizing a Daoist World. In N. Girardot, J. Miller \& X. Liu X (ed.) Daoism and Ecology: Ways within a Cosmic Landscape (pp. 265-322). Cambridge, Mass: Harvard University Press.

Bai, S. (2016). Award-Winning Sci-Fi Writer Ken Liu On Labels, Authenticity, and Juggling Two Careers. NBC News. 8 March 2016. https://www.nbcnews.com/news/asian-america/award-winning-scifi-writer-ken-liu-labels-authenticity-juggling-n533586.

Baoshu. (2015). 大时代 Dashidai [What Has Passed Shall in Kinder Light Appear]. The Magazine of Fantasy and Science Fiction March-April.

Barnwell, S. A. (2013). The Evolution of the Concept of De 德 in Early China. Philadelphia: University of Pennsylvania, Sino-Platonic Papers 235.

Bostrom, N. (2016). Are You in a Computer Simulation? In S. Schneider (ed.) Science Fiction and Philosophy: From Time Travel to Superintelligence. West Sussex: John Wiley \& Sons.

Buswell, R. E. Jr \& D. S. Lopez Jr. (2013). Buddhābhișeka. In The Princeton Dictionary of Buddhism (pp. 150). Princeton: Princeton University Press.

Chan, A. (2000). The Daode jing and its tradition. In L. Kohn (ed.) Daoism Handbook (pp. 1-29). Leiden, Boston and Koln: Brill.

Chan, A. (2010). Introduction. In A. K. L. Chan \& Y.-K. Lo (ed.) Philosophy and Religion in Early Medieval China (pp. 1-22). Albany, NY: State University of New York Press.

Chan, A. (2018). Laozi. In E. N. Zalta (ed.) The Stanford Encyclopedia of Philosophy.

https://plato.stanford.edu/archives/win2018/entries/laozi/.

Chao, X. (2015). 陈楸帆: 对科幻创作, 着迷于介于不同类型间的模糊与 游离 Chen Qiufan: Dui kehuan chuangzuo, zhaomiyu jieyu butong leixingjiande mohu yu youli [Chen Qiufan: The creation of science fiction focuses on blurred boundaries between different types]. China Writer. $23 \quad$ October 2015. http://www.chinawriter.com.cn/news/2015/2015-1023/256238.html.

Chen, N. (1997a). The Concept of Fate in Mencius. Philosophy East \& West, 47.4, 495-520.

Chen, N. (1997b). The Genesis of the Concept of Blind Fate in Ancient China. Journal of Chinese Religions, 25, 141-67. 
Chen, Q. (2012). 未来病史 Weilai bingshi [A History of Future Illnesses]. 文 艺风赏Wenyi Fengshang April-December.

Chen, Q. (2015). 开光 Kaiguang [Coming of the Light]. 离线・黑客 Lixian $\bullet$ Heike [Offline $\bullet$ Hacker] January.

China Daily. (2015). China's Arthur C. Clarke. China Daily. 24 August 2015. https://language.chinadaily.com.cn/201508/24/content 21688078 2.htm.

China Daily. (2019). Liu Cixin. China Daily. 18 April 2019. http://shanxi.chinadaily.com.cn/yangquan/201904/18/c 356401.htm.

Coutinho, S. (2016). Zhuangzi and Early Chinese Philosophy: Vagueness, Transformation and Paradox. London and New York: Taylor \& Francis Group.

D’Ambrosio, P. J. (2016). Wei-Jin Period Xuanxue 'Neo-Daoism': Re-working the Relationship Between Confucian and Daoist Themes. Philosopby Compass, 11, 621-631.

Dong, M. (2020). 科幻作家陈楸帆: AI 写作时代的到来, 会终结科幻吗? Kehuan zuojia Chen Qiufan: AI xiezuo shidaide daolai, hui zhongjie kehua ma [Science-fiction writer Chen Qiufan: Will the arrival of AI era end science fiction?]. Beijing News. 28 August 2020. https://www.bjnews.com.cn/detail/159858601415768.html.

Fan, J. (2019). Liu Cixin's War of the Worlds: A leading sci-fi writer takes stock of China's global rise. The New Yorker. 17 June 2019. https://www.newyorker.com/magazine/2019/06/24/liu-cixins-warof-the-worlds.

Fraser, C. (2011). Emotion and Agency in Zhuangzi. Asian Philosophy, 21.1, 97-121.

Global Times. (2015). The future of Chinese sci-fi: An interview with China's first Hugo Award winner: Liu Cixin. Global Times. 30 August 2015. https://www.globaltimes.cn/content/939761.shtml.

Graham, A. C. (1989). Disputers of the Tao: Philosophical Argument in Ancient China. La Salle, Ill.: Open Court Publishing Company.

Gu, B. (2020). 宝树访谈: 科幻作家眼中的瘟疫 Baoshu fangtan: Kehuan zuojia yanzhongde wenyi [An interview with Baoshu: Plague in the eyes of a science-fiction writer]. China Writer. 14 April 2020. http://www.chinawriter.com.cn/n1/2020/0414/c40408031672737.html.

Gu, S. (2013). 倒影 Daoying [Reflection]. 超好看 Chaobaokan [Super Nice Magazine 7 July.

Hansen, C. (2014). Zhuangzi. In E. N. Zalta (ed.) The Stanford Encyclopedia of Philosophy. https://plato.stanford.edu/entries/zhuangzi/.

Henriksen, E. (2019). Broken Stars Gives a Tantalizing Glimpse of All That Chinese Science Fiction Has to Offer. Tor. 25 February 2019. https://www.tor.com/2019/02/25/book-reviews-broken-stars- 


\section{anthology-ken-liu/.}

Kirkland, R. (2004). Taoism: The Enduring Tradition. London: Routledge.

Kohn, L. (2014). Zhuangzi: Text and Context. St Petersburg: Three Pines Press.

Kupperman, J. (1993). Zhuangzi on Skepticism, Skill, and the Ineffable Dao. Journal of the American Academy of Religion, 61.4, 639-954.

Ivanhoe, P. J. (1996). Was Zhuangzi a Relativist? In P. Kjellberg \& P. J. Ivanhoe (ed.) Essays on Skepticism, Relativism, and Ethics in the Zhuangai (pp. 196-214). Albany: State University of New York Press.

Lenehan, K. (2020). Zhuangzi's discourse on 'contented acceptance of fate' and its relation to catastrophe. Educational Philosophy and Theory, 52(6), $1-12$.

Li, W. (2015). 中国科幻作家刘慈欣凭《三体》获雨果奖 Zhonguo kehuan zuojia Liu Cixin ping Santi huo yuguojiang [A Chinese sciencefiction writer Liu Cixin won a Hugo Award with The three-body problem]. BBC News. 23 August 2015. https://www.bbc.com/zhongwen/simp/china/2015/08/150823 chi na book prize.

Liu, C. (2009). 月夜 Yueye [Moonlight]. 生活 Shenghuo [Life] February.

Liu, K. (2016). Introduction: China dreams. In Invisible Planets: Contemporary Chinese Science Fiction in Translation, Ed and Trans, Ken Liu. Tor Books.

Liu, K. (2019). Ed and Trans. Broken Stars: Sixteen Stories from the New Frontiers of Chinese Science Fiction. London: Head of Zeus.

Liu, X. (1994). Classifying the Zhuangri Chapters. Ann Arbor: University of Michigan Press.

Liu, X. (2015a). Did Taoism have a founder? Textual issues of the Laozi. In X. Liu (ed.) Dao Companion to Daoist Pbilosophy (pp. 25-46). New York and London: Springer.

Liu, X. (2015b). Zhuangzi's Philosophy: A Three Dimensional Reconstruction. In X. Liu (ed.) Dao Companion to Daoist Philosophy (pp. 193-220). New York and London: Springer.

Liu, X. (2015c). Textual issues in the Zhuangzi. In X. Liu (ed.) Dao Companion to Daoist Philosophy (pp. 129-158). New York and London: Springer.

Lynn, R. J. (2016). Trans. Zhuangzi: A New Translation of the Daoist Classic as Interpreted by Guo Xiang. New York: Columbia University Press.

Mair, V. (2000). The Zhuangzi and its impact. In L. Kohn (ed.) Daoism Handbook (pp. 30-52). Leiden, Boston and Koln: Brill.

Moeller, H.-G. (2003). Idiotic Irony in the Zhuangzi. Chinese Literature: Essays, Articles, Reviews, 30, 117-123.

Moeller, H.-G. (2004). Daoism Explained: From the Dream of the Butterfly to the Fishnet Allegory. La Salle, IL: Open Court Publishing.

Myers, R. E. (1983). Introduction: Exploring the Exploration. In R. E. Myers (ed.) The Intersection of Science Fiction and Philosophy: Critical Studies (pp. ixxvi). Westport, Connecticut and London: Greenwood Press.

Nadeau, R. L. (2014). Asian Religions: A Cultural Perspective. Malden and Oxford: John Wiley \& Sons. 
Nylan, M. (1993). The Canon of Supreme Mystery. Albany: State University of New York Press.

Peerenboom, R. P. (1993). Law and Morality in Ancient China: The Silk Manuscripts of Huang-Lao. Albany: State University of New York Press.

Poo, M.-c. (2005). How to Steer through Life: Negotiating Fate in the Daybook. In C. Lupke (ed.) The Magnitude of Ming: Command, Allotment, and Fate in Chinese Culture (pp. 107-125). Honolulu: University of Hawaii Press.

Radice, T. (2001). Clarity and Survival in the Zhuangzi. Asian Philosophy, 11.1, $33-40$.

Raphals, L. (2003). Fate, Fortune, Chance, and Luck in Chinese and Greek: A Comparative Semantic History. Philosophy East \& West, 53.4, 537-74.

Raphals, L. (2005). Languages of Fate: Semantic Fields in Chinese and Greek. In C. Lupke (ed.) The Magnitude of Ming: Command, Allotment, and Fate in Chinese Culture (pp. 70-106). Honolulu: University of Hawaii Press.

Schneider, S. (2016). Introduction Thought Experiments: Science Fiction as a Window into Philosophical Puzzles. In S. Schneider (ed.) Science Fiction and Philosophy: From Time Travel to Superintelligence. West Sussex: John Wiley \& Sons.

Schwartz, B. (1985). The World of Thought in Ancient China. Cambridge, Mass: Harvard University Press.

Shen, J. (2020). 科幻作家陈楸帆: 2020 思考了什么 Kehuan zuojia Chen Qiufan: 2020 sikaole shenme [Science-fiction writer Chen Qiufan: What I've thought in 2020]. China Youth Daily. 24 November 2020. http://www.chinawriter.com.cn/n1/2020/1124/c40505731941687.html.

Shun, K.-L. (1997). Mencius and Early Chinese Thought. Stanford: Stanford University Press.

Waley, A. (2005). The Way and Its Power: A Study of the Tao Tê Ching and Its Place in Chinese Thought. London and New York: Routledge.

Watson, B. (1968). Trans. The complete works of Chuang Tru. New York: Columbia University Press.

Watson, M. (2015). Bao Shu. What Has Passed Shall in Kinder Light Appear. (Fantasy and Science Fiction Mar/Apr 2015). Best SF. 15 June 2015. http://bestsf.net/bao-shu-what-has-passed-shall-in-kinder-lightappear-fantasy-and-science-fiction-marapr-2015/.

Wong, D. B. (2005). Zhuangzi and the Obsession with Being Right. History of Philosophy Quarterly, 22.2, 91-108.

Wu, A. (2014). 宇宙尽头的餐馆腊八粥 Yuzhou jintoude canguan labazhou [The Restaurant at the End of the Universe: Laba Porridge]. 最小说 Zui Xiaoshuo [Zui Novel] May.

Wu, K.-m. (1982). Chuang-tzu: World Philosopher at Play. Albany: State University of New York Press.

Yu，X. (2021). 后人类时代的潮汕一一陈楸帆科幻中的故乡书写 
Hourenlei shidaide Chaoshan-Chen Qiufan kehuan zhongde guxiang shuxie [Chaoshan area in the post-human era-Hometown representation in Chen Qiufan's science-fiction works]. Yangtre Jiang Literary Review. $16 \quad$ August 2021. http://www.chinawriter.com.cn/n1/2021/0816/c40408032194049.html.

Zhang, D. (2002). Key Concepts in Chinese Philosophy. New Haven, Conn.: Yale University Press.

Zhang, J. (2016). 《三体》《北京折叠》译者刘宇昆: 两次获得 “雨果 奖” Santi Beijing zhedie yizhe Liu Yukun: Liangci huode Yuguojiang [The translator of The three-body problem and Folding Beijing: Liu Yukun has won Hugo Award twice]. Huaxi Dushi Bao. 31 August 2016. http://culture.people.com.cn/n1/2016/0831/c22219-28679601.html.

Zhang, R. (2014). 晋阳三尺雪 Jinyang Sanchixuan [The Snow of Jinyang]. 新科幻Xinkehuan [New Science Fiction] January.

Zhao, Y. (2012). 科幻最高双奖得主刘宇昆: 受严歌苓影响写就东方色 彩 Kehuan zuigao shuangjiang dezhu Liu Yukun: Shou Yan Geling yingxiang xiejiy dongfang secai [Winner of the highest science-fiction award Liu Yukun: Oriental representation influenced by Yan Geling]. $\begin{array}{lllll}\text { China } & \text { Writer } & 27 & \text { September } & 2012 .\end{array}$ http://www.chinawriter.com.cn/wxpl/2012/2012-0927/142520.html.

Zhao, Y. (2019). 中国当代科幻小说选集《碎星星》推出英文版 Zhongguo dangdai kehuan xiaoshuo xuanji Suixingxing tuichu yingwenban [The English version of contemporary Chinese sciencefiction collection Broken stars has been released]. Shenzhen Economic Daily. 